\title{
Diatom Pseudo-nitzschia cf. caciantha (Bacillariophyceae), the Most Likely Source of Domoic Acid Contamination in the Thorny Oyster Spondylus versicolor Schreibers 1793 in Nha Phu Bay, Khanh Hoa Province, Vietnam
}

\author{
DAO VIET HA ${ }^{1 *}$, PO TEEN LIM ${ }^{2}$, PHAM XUAN KY ${ }^{1}$, YOSHINOBU TAKATA ${ }^{3}$, SING \\ TUNG TENG $^{4}$, TAKUO OMURA ${ }^{3}$, YASUWO FUKUYO ${ }^{3}$ and MASAAKI KODAMA ${ }^{3}$ \\ ${ }^{1}$ Institute of Oceanography, Vietnam Academy of Science and Technology, 01 Cau Da Street, Nha Trang City, Khanh \\ Hoa Province, Vietnam \\ ${ }^{2}$ Marine Research Station, Institute of Ocean and Earth Science, University Malaya, 16310 Bachok, Kelantan, Malaysia \\ ${ }^{3}$ The University of Tokyo, Yayoi 1-1-1, Bunkyo-Ku, Tokyo, 113-8657, Japan \\ ${ }^{4}$ Faculty of Resource Science and Technology, Universiti Malaysia Sarawak, 94300 Kota Samarahan, Sarawak, \\ Malaysia
}

\begin{abstract}
Domoic acid (DA) contamination in the thorny oyster Spondylus versicolor Schreibers 1793 was discovered in 2005, in Nha Phu Bay, Khanh Hoa Province, Vietnam. Concurrently, DA was detected in the net-plankton samples. The causative organism responsible for the DA was not detected then. In 2006, DA in S. versicolor (maximum of $43.6 \mu \mathrm{g} \cdot \mathrm{g}^{-1}$ ) and in net-plankton samples (maximum of $0.78 \mathrm{ng} \cdot \mathrm{L}^{-1}$ ) recurred, suggesting the existence of DA producers in the bay. When DA in S. versicolor again increased in 2007, a net-plankton sample was collected, and cultures of Pseudo-nitzschia species were established for DA analysis and species identification. Eight out of eleven cultured isolates of Pseudo-nitzschia spp. showed DA production $\left(111-244 \mathrm{ng} \cdot \mathrm{mL}^{-1}\right)$, as confirmed by liquid chromatography-tandem mass spectroscopy. The toxic isolates examined by transmission electron microscopy shared identical morphological characteristics: a single row of poroids, hymens divided into 2-6 sectors, and mantles 1-2 poroids high. They resembled Pseudonitzschia caciantha Lundholm, Moestrup \& Hasle, 2003 thus we designated it as $P$. cf. caciantha. Our results indicated that $P$. cf. caciantha most likely contributed to the DA contamination in $S$. versicolor in Nha Phu Bay. This is the first report of DA production by $P$. cf. caciantha anywhere in the world.
\end{abstract}




\section{Introduction}

In 1987, more than 100 people were hospitalised and three died, after consuming blue mussels, Mytilus edulis Linnaeus 1758, from Prince Edward Island, Canada (Bates et al. 1989). Victims showed both gastrointestinal and neurological symptoms, including nausea, disorientation, and temporary amnesia. In more serious cases, gastric lesions, persistent short-term memory loss and/or coma also occurred (Perl et al. 1990). The poisoning syndrome was named Amnesic Shellfish Poisoning (ASP) owing to the fact that the poisoned victims experienced memory loss (Todd 1990). The toxic agent in the Canadian incident was ascertained to be domoic acid (DA), which contaminated the blue mussels, and the plankton species responsible was identified as the pennate diatom Pseudo-nitzschia multiseries (Bates et al. 1989). No human intoxication by DA has been reported since then. However, DA poisoning has been widely associated with deaths of marine mammals and birds (reviewed in Lelong et al. 2012; Trainer et al. 2012). Accumulation of DA in bivalves was also reported from various parts of the world (Trainer et al. 2012). DA contamination in bivalves has received additional research attention from the standpoint of public health. These studies have been confined to temperate and sub-polar regions, with little information in tropical regions. However, several potentially toxic Pseudo-nitzschia species have been reported in the tropics, including Malaysia (Lim et al. 2010, 2012, 2013; Teng et al. 2013 and in press) and Vietnam (Skov et al. 2004; Doan et al. 2013), suggesting more attention should be given to studies of ASP and DA contamination in the region.

Takata et al. (2009) reported that a significant level of DA was detected consistently in bivalves of the genus Spondylus (thorny oyster) collected from various tropical areas, including Vietnam. In Nha Phu Bay, Khanh Hoa Province, three Spondylus species such as S. versicolor, Spondylus cruentus Lischke, 1868 and Spondylus squamosus Schreibers, 1793 are found. Among them, $S$. versicolor is known as the most popular commercial species that is consumed in many local restaurants. Thus, it is important from the standpoint of public health to collect information about DA accumulation in this species. Interestingly, Dao et al. (2009a) showed a clear relationship between DA in $S$. versicolor and in net-plankton samples collected from Nha Phu Bay, Khanh Hoa Province, Vietnam, in 2005. These findings revealed that DA-producing organisms in the plankton could be the source of DA accumulated in $S$. versicolor in the bay. However, no known toxigenic Pseudo-nitzschia species were observed in the plankton samples containing DA. The following year (2006), Dao et al. (2009b) reported that DA was mostly concentrated in the small-sized fraction of net-plankton samples in which Pseudo-nitzschia spp. were the dominant species. Based on these previous findings, this study was undertaken to investigate potential sources of DA in Nha Phu Bay, with emphasis on the genus Pseudo-nitzschia. Unialgal cultures of Pseudo-nitzschia species were established from the plankton samples for species identification and DA analysis. 


\section{Materials and Methods}

\section{Sampling}

Five individuals of $S$. versicolor were collected fortnightly at $3 \mathrm{~m}$ depth by scuba diving, at a site nearby Hon Thi Island, Nha Phu Bay $\left(12^{\circ} 38^{\prime} 42^{\prime \prime} \mathrm{N}, 109^{\circ} 22^{\prime} 06^{\prime \prime} \mathrm{E}\right)$, Khanh Hoa Province, Vietnam during March and April 2006. Sampling frequency was increased to twice weekly from 22 August to 29 September, then monthly until December 2006. Plankton samples were collected at the same time using a $20-\mu \mathrm{m}$ mesh-size plankton net (30-cm diameter) by hauling the net vertically 20 times from a 2-m depth to the surface, concentrating the phytoplankton to a final volume of $250 \mathrm{~mL}$.

On 17 April 2007, when DA in S. versicolor increased (to $17.0 \mu \mathrm{g} \cdot \mathrm{g}^{-1}$ ) (Dao et al. 2009b), plankton samples were collected to establish cultures. Samples collected by the plankton net were kept in $250 \mathrm{~mL}$ plastic bottles in darkness, without any preservative, and brought back to the laboratory for single-cell isolation and identification.

\section{Sample preparation and extraction of domoic acid in field samples}

The live $S$. versicolor individuals were taken to the laboratory (Department of Biochemistry, Institute of Oceanography) within $2 \mathrm{~h}$ of sampling. Whole tissues from each individual of $S$. versicolor were homogenised in 50\% methanol, with a ratio of $1: 4(\mathrm{w} / \mathrm{v})$, prior to centrifugation $(10,000 \times g, 20 \mathrm{~min})$ (Quilliam et al. 1989). One milliliter of crude extract obtained from one animal was equivalent to $\sim 0.2 \mathrm{~g}$ of soft tissue.

For toxin analysis of the plankton, $120 \mathrm{~mL}$ of the concentrated net sample were filtered onto a glass-fiber filter (GF/F, Whatman, USA) and extracted by sonication for $5 \mathrm{~min}$ in $10 \mathrm{~mL}$ of $50 \%$ methanol. The mixture was then centrifuged $(10,000 \times g, 30 \mathrm{~min})$ to separate the toxin extract and cells debris (Quilliam 2003). The crude extracts obtained were filtered through an ultrafiltration membrane (NMWL 5,000, Millipore, USA) and kept at $-20{ }^{\circ} \mathrm{C}$ for later DA analysis.

\section{Analysis of domoic acid in S. versicolor and plankton samples}

DA extracts from $S$. versicolor and plankton samples were analysed by UV-HPLC (Shimadzu SPD-20A, Japan) according to Kodama and Kotaki (2005). The mean DA concentration from five $S$. versicolor extracts was calculated, and results are expressed as $\mu \mathrm{g} \mathrm{DA} \cdot \mathrm{g}^{-1}$ of soft tissue for $S$. versicolor or $\mathrm{ng} \mathrm{DA} \cdot \mathrm{L}^{-1}$ of seawater in plankton samples. 


\section{Cultures of Pseudo-nitzschia species}

Single cells or chains of cells of Pseudo-nitzschia spp. from the net sample collected on 17 April 2007 were isolated individually to establish clonal cultures, under an inverted microscope. Cells were rinsed several times with $0.2-\mu \mathrm{m}$ filtered seawater before transferring into a 24 -multiwell plate containing $1 \mathrm{~mL}$ of modified $\mathrm{T} 1$ medium (Ogata et al. 1987), with addition of $3.52 \mu \mathrm{M}$ silicate at a salinity of $30 \mathrm{ppt}$. The inoculated plates were maintained at $26{ }^{\circ} \mathrm{C}$ under a light intensity of 150 $\mu \mathrm{mol} \cdot$ photons $\cdot \mathrm{m}^{-2} \cdot \mathrm{s}^{-1}$, with a 12:12-h light:dark cycle. After 4 days, the cells were transferred into test tubes, and maintained at the same condition. Ten $\mathrm{mL}$ of a week-old culture were subsampled for DA analysis and morphological observation. A culture growth curve was not determined.

\section{Analysis of domoic acid in the cultures}

Ten $\mathrm{mL}$ of culture were sonicated for $5 \mathrm{~min}$ to break the cell walls and then centrifuged $(10,000 \times g, 30 \mathrm{~min})$ to obtain the supernatant. The $\mathrm{pH}$ of the supernatant was adjusted to $2-3$ using $1 \mathrm{~N}$ hydrochloric acid. Samples were filtered slowly through Sep-Pak C18 cartridges (Water associations, USA). The DA extract was eluted with $10 \mathrm{~mL}$ of methanol. The aqueous methanolic elution was evaporated at $35^{\circ} \mathrm{C}$ to remove methanol and dissolved in $1 \mathrm{~mL}$ of distilled water. DA in cultures was analysed by a UV-HPLC analyser as described above. Cells were not enumerated; as such, cellular DA was not determined quantitatively. DA is expressed as the presence of DA in 1 $\mathrm{mL}$ of culture.

Extracts from the cultured Pseudo-nitzschia cells that contained DA detected by HPLC analysis were further analysed by liquid chromatography-tandem mass spectroscopy (LC-MS/MS) (API-2000, Applied Biosystems, CA, USA) (Takata et al. 2009). The aqueous solution of DA (Diagnostic Chemicals Limited, Charlottetown, PEI, Canada), the concentration of which was calibrated using DA standard DACS-1C (National Research Council of Canada), was used for the reference toxin for UV-HPLC and LC-MS/MS analysis.

\section{Identification of the cultured Pseudo-nitzschia species}

The cell length and width of cultured strains were measured under a light microscope. Cells for transmission electron microscopy (TEM) were acid washed to remove organic materials, following Hargraves and Guillard (1974) with some modifications. Cells in the centrifuge tubes required initial washing with distilled water to remove excess salt. This was followed by an acid wash, using a mixture of potassium permanganate (2-3 crystals) and concentrated sulfuric acid (3-4 $\mathrm{mL}$ ) that was added to $1 \mathrm{~mL}$ of residue to remove organics. After cooling, 5\% oxalic acid was added to the suspension until the purple colour disappeared, and the cell slurry was then rinsed several times to remove excess acid. A few drops of the cell suspension were mounted onto a Formvarcoated grid and oven-dried. The acid-washed samples were observed under a JEM-1010 TEM. Species of Pseudo-nitzschia were identified based on morphological characteristics according to Skov et al. (1999), Lundholm et al. (2003) and Teng et al. (2013). 


\section{Results}

Seasonal variation of domoic acid in Spondylus versicolor and in net-plankton samples during 2006

The seasonal variation of DA in S. versicolor and net-plankton samples, from 24 March 2006 to 28 December 2006, is shown in Fig. 1. From March to August, the DA level in S. versicolor fluctuated from 9.2 to $16.2 \mu \mathrm{g}^{-1} \mathrm{~g}^{-1}$, while no DA was detected in the net-plankton samples collected during this period. DA was detected in plankton samples collected from 22 August, at a trace level $\left(0.05 \mathrm{ng} \cdot \mathrm{L}^{-1}\right)$, and reached a maximum level $\left(0.78 \mathrm{ng} \cdot \mathrm{L}^{-1}\right)$ on 29 August.

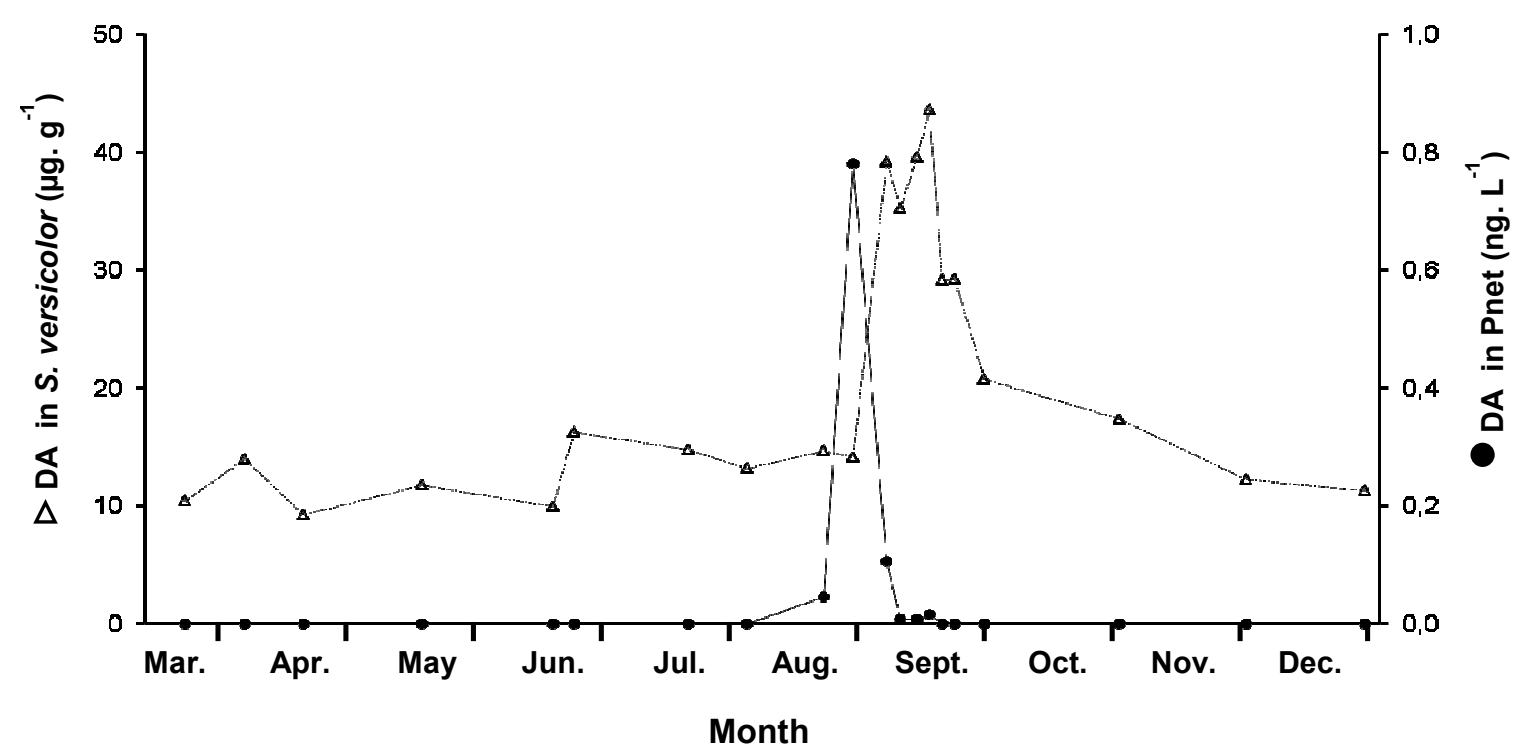

Fig. 1. Seasonal variation of domoic acid (DA) in Spondylus versicolor and net plankton samples (Pnet) collected in Nha Phu Bay, in 2006.

Subsequently, DA in S. versicolor rapidly increased from $14.7 \mu \mathrm{g} \cdot \mathrm{g}^{-1}$ on 29 August to reach its maximum $\left(43.6 \mu \mathrm{g} \cdot \mathrm{g}^{-1}\right)$ on 16 September. It then decreased to $20.8 \mu \mathrm{g} \cdot \mathrm{g}^{-1}$ on 29 September and returned to the pre-bloom level by 28 December, while no DA was detected in net-plankton samples (Fig. 1).

\section{Domoic acid in Pseudo-nitzschia cultures}

Eleven clonal cultures of Pseudo-nitzschia spp. were established. Results from the HPLC analysis showed detectable DA $\left(111-244 \mathrm{ng} \cdot \mathrm{mL}^{-1}\right)$ in 8 of 11 isolates. Further DA confirmation of these culture extracts by LC-MS/MS showed a peak at the same retention time as that of the DA standard, with the pseudo-molecular ion $[\mathrm{M}+\mathrm{H}]^{+}(\mathrm{m} / \mathrm{z} 312)$. Fragmentation patterns of daughter ions characteristic of DA $(\mathrm{m} / \mathrm{z} 266,248,161)$ were observed consistently in the culture extracts (Fig. 2). 


\section{Species identification of Pseudo-nitzschia culture strains}

\section{Descriptions of Pseudo-nitzschia $c f$. caciantha}

Cells are lanceolate, $46.7-50.7 \mu \mathrm{m}$ long and $2.7-4.0 \mu \mathrm{m}$ wide, and show a 1/5-1/6 overlap in the stepped chain (Fig. 3a, Table 1). The valve comprises 15-18 fibulae and 28-30 striae in $10 \mu \mathrm{m}$. Each stria contains one row of round to square poroids, with 4-5 poroids in $1 \mu \mathrm{m}$. The hymen of the poroids is divided into 2-6 sectors, mainly $4-5$ sectors (Fig. 3b, Table 1). Central sectors in the poroids were present in $12-28 \%$ of the cells (Fig. $3 b$, Table 1). The proximal and distal mantles of the valve are 1-2 poroids high (Fig. 3b, Table 1).
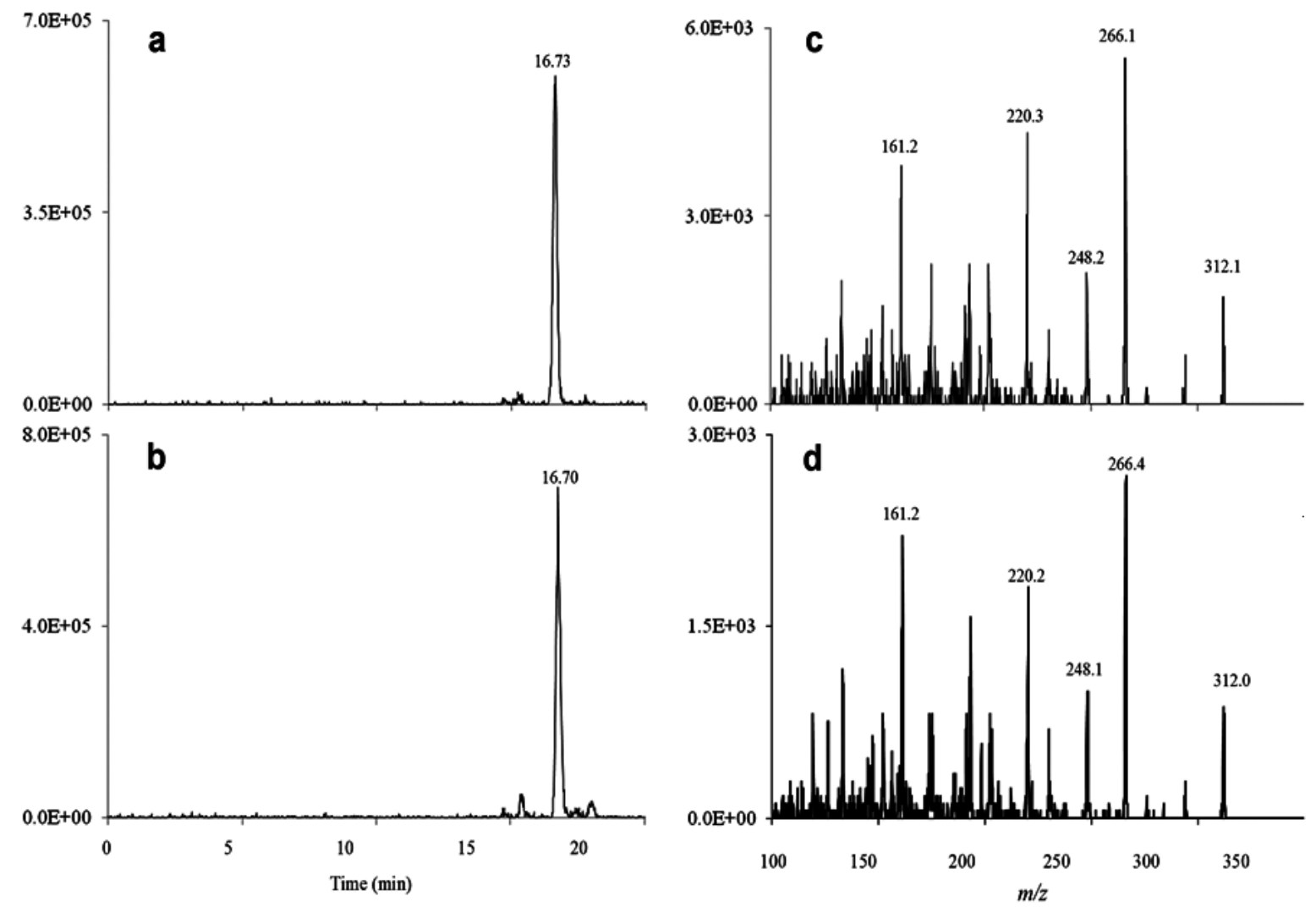

Fig. 2. LC-MS/MS spectra showing DA peak (arrowhead) of extract of a Pseudo-nitzschia cf. caciantha culture, sampled 7 days after inoculation. (a) Elution pattern of DA standard in LC scanned by $(\mathrm{M}+\mathrm{H})^{+} 312 \mathrm{~m} / z$; (b) Elution pattern of a $P$. cf. caciantha culture in LC scanned by $(\mathrm{M}+\mathrm{H})^{+} 312 \mathrm{~m} / \mathrm{z}$; (c) Fragmentation pattern of DA standard; (d) Fragmentation pattern of a $P$. cf. caciantha culture.

Frustules of all the observed toxic isolates shared similar morphological characteristics, as described above, and resembled $P$. caciantha. No DA was detected in extracts of the other cultured isolates, which were identified as $P$. brasiliana (two isolates) and $P$. pungens (one isolate) (data not shown). 


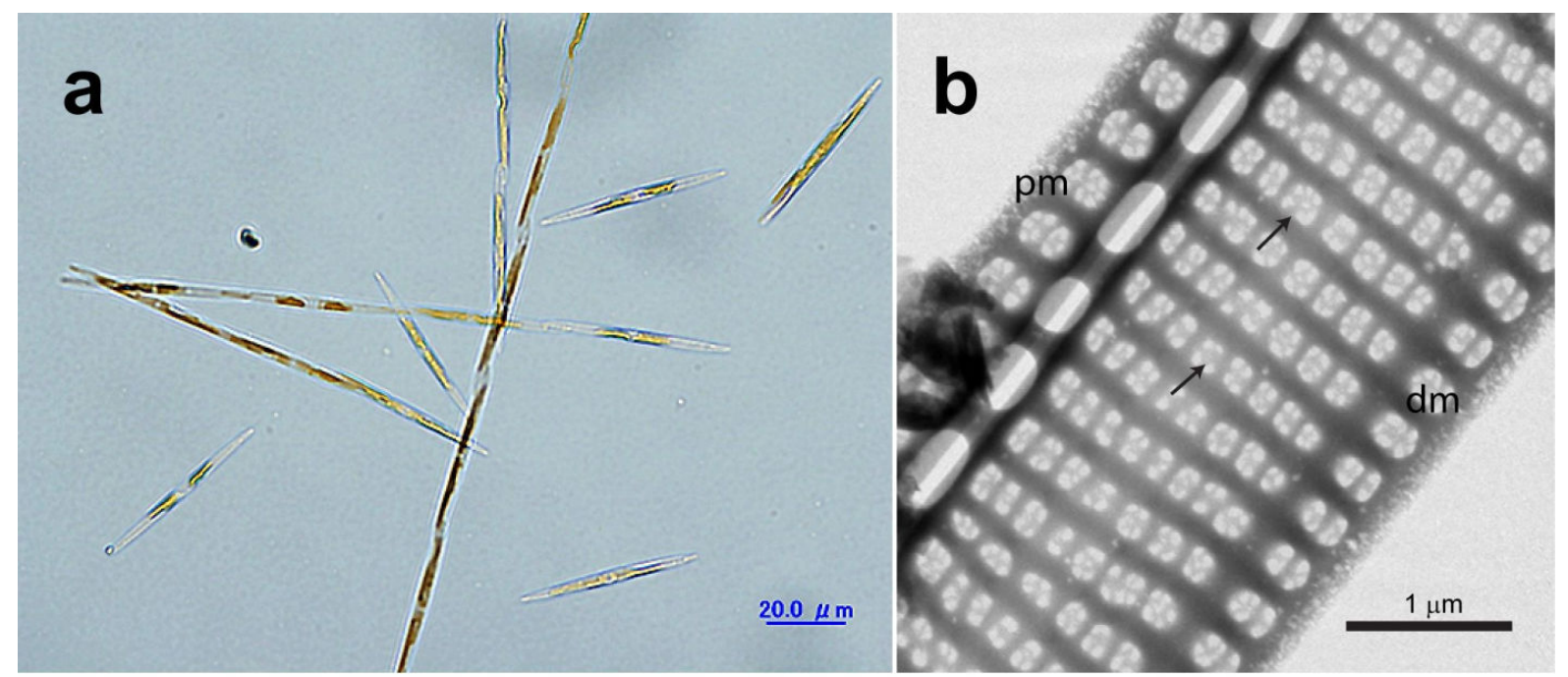

Fig. 3. Images of Pseudo-nitzschia cf. caciantha under (a) LM, showing chains of cells and single cells; and (b) TEM, showing poroid structure with hymens divided into 2-6 sectors (arrows); proximal mantle (pm) and distal mantle (dm) are two poroids high.

\section{Discussion}

Although the average level of DA in $S$. versicolor during the peak period in the present study (43.6 $\left.\mu \mathrm{g} \cdot \mathrm{g}^{-1}\right)$ was lower than in $2005\left(146.8 \mu \mathrm{g} \cdot \mathrm{g}^{-1}\right.$ ) (Dao et al. 2009a), it was still more than twice the safety consumption level $\left(20 \mu \mathrm{g} \cdot \mathrm{g}^{-1}\right)$ set by the Canadian Food Inspection Agency, a regulatory authority. In Vietnam, there is no regulation for DA in domestic markets, although the government sets an action level of $20 \mu \mathrm{g} \cdot \mathrm{g}^{-1}$ for exported seafood product. Other species of the genus Spondylus, e.g. S. squamosus and S. cruentus, are also delicacies in local markets; however, DA contamination in these species is unknown. Food poisonings, with symptoms similar to those of ASP, have often been observed in individuals who had consumed 3-5 Spondylus animals in Khanh Hoa Province. Further studies on DA in Spondylus, including the other species in the area, are necessary.

The seasonal occurrences of DA in the thorny oyster $S$. versicolor and in the net-plankton samples collected from Nha Phu Bay during 2006 are similar to those during 2005 (Dao et al. 2009a). However, in 2006, the peak of DA in S. versicolor and in net samples occurred in AugustSeptember, whereas in 2007, it was observed in April (Dao et al. 2009b). The phenomenon recurred, suggesting there could be an annual appearance of the causative microalgae in Nha Phu Bay, although perhaps at different times of the year. DA in $S$. versicolor reached a maximum level about 2 weeks after the peak in the DA-producing plankton. This supports the conclusion that $S$. versicolor accumulated DA by ingesting toxic plankton that co-occurred in the water.

The level of DA in net-plankton samples in this study $\left(0.78 \mathrm{ng} \cdot \mathrm{L}^{-1}\right)$ was much lower than that reported in other studies, e.g. 9,390 ng $\cdot \mathrm{L}^{-1}$ for San Francisco Bay (Howard et al. 2007) and 14,300 $\mathrm{ng} \cdot \mathrm{L}^{-1}$ for Washington State inland waterways (Trainer et al. 2007). 
Differences in sampling methods may account for the lower particulate DA values in our study. In the above studies, cells were collected by filtering a known volume of water through a glass-fiber filter, and all of the cells were then extracted, thus allowing an accurate measurement of ng DA $\mathrm{L}^{-1}$. In contrast, in the present study, the water volume "filtered" by the $20-\mu \mathrm{m}$ mesh-size plankton net was not quantified, so that the $D A \cdot L^{-1}$ value is not a true representation of the $D A \cdot L^{-1}$ in the environment. Rather, the value represents the DA in the concentrated cell extract, obtained from perhaps slightly different volumes of seawater. Furthermore, the cell density of Pseudo-nitzschia was often low in Nha Phu Bay (Dao et al. 2009b), requiring up to 20 vertical net hauls to collect sufficient Pseudo-nitzschia cells, although an increasing number of cells were trapped as the mesh pores became clogged. Because the plankton net was always hauled 20 times, comparisons can still be made from one sampling time to the next, making the data shown in Fig. 1 still valid for this purpose. On the other hand, DA in the present study was also lower than that reported by Takahashi et al. (2007) from Queensland, Australia $\left(120 \mathrm{ng} \cdot \mathrm{L}^{-1}\right)$, in which plankton net (30- $\mu \mathrm{m}$ mesh size) was used for sample collection. The variation in the findings could be due to the size differences in the DA-producing species in the two areas. In Nha Phu Bay, Dao et al. (2009b) reported that the possible DA source could be the narrow-celled plankton group, many of which may not be trapped by the plankton net. The data therefore suggest that the use of plankton net was not the optimum method for collecting Pseudo-nitzschia cells in this study.

The peak of DA in $S$. versicolor occurred about 2 weeks after the DA peaked in the net plankton, suggesting that monitoring for Pseudo-nitzschia spp. could provide an early warning of impending DA contamination in the shellfish, as was the case in eastern Canada (Bates et al. 1998). Although the DA in $S$. versicolor was at the highest level, it rapidly depurated after the DAproducing plankton are no longer in the environment. Others have also reported that DA accumulated in certain bivalves during a bloom of toxic Pseudo-nitzschia spp. rapidly depurated from the bivalve, after the causative toxic species was no longer present. For example, Novaczek et al. (1992) reported that mussels (Mytilus edulis) containing up to $50 \mu \mathrm{g} \mathrm{DA} \cdot \mathrm{g}^{-1}$ depurated the DA to trace or residual levels after $72 \mathrm{~h}$.

However, some bivalve species retain DA for a long period (reviewed in Trainer et al. 2012). Dao et al. (2006) also reported that a low level of DA remained in $S$. versicolor (referred as $S$. cruentus) during a 45-day period. Therefore, in the present study, the low level of DA that remained in S. versicolor until December 2006, after its peak in September, could be a result of its ability to retain a certain amount of DA for a long period. 
Table 1. Comparison of morphometric data of Pseudo-nitzschia $\mathrm{cf}$. caciantha with its closely related species in the P. pseudodelicatissima complex; means \pm SD are shown in parentheses. $n$ : number of cells measured. All species showed only one row of poroids between the interstriae. The presence or absence of a central interspace could not be confirmed.

\begin{tabular}{|c|c|c|c|c|c|c|c|c|}
\hline Species & Valve shape & Length & Width & $\begin{array}{c}\text { Fibulae in } \\
10 \mu \mathrm{m}\end{array}$ & $\begin{array}{c}\text { Striae in } \\
10 \mu \mathrm{m}\end{array}$ & $\begin{array}{l}\text { Hymen } \\
\text { sectors }\end{array}$ & $\begin{array}{l}\text { Poroids } \\
\text { in } 1 \mu \mathrm{m}\end{array}$ & Reference \\
\hline P. cf. caciantha & $\begin{array}{l}\text { Lanceolate, } \\
\text { asymmetrical }\end{array}$ & $\begin{array}{c}46.7-50.7 \\
(47.7 \pm 1.9) \\
n=8\end{array}$ & $\begin{array}{c}2.7-3.7 \\
(3.2 \pm 0.5) \\
n=8\end{array}$ & $\begin{array}{c}15-18 \\
(16.5 \pm 1.3) \\
n=4\end{array}$ & $\begin{array}{c}28-30 \\
(29 \pm 1) \\
n=5\end{array}$ & $\begin{array}{c}(2) 3-6 \\
(3.9 \pm 0.9) \\
n=72\end{array}$ & $\begin{array}{c}4.0-5.0 \\
(4.4 \pm 0.5) \\
n=12\end{array}$ & This study \\
\hline P. caciantha & $\begin{array}{l}\text { Lanceolate, } \\
\text { asymmetrical }\end{array}$ & $53-75$ & $2.7-3.5$ & $15-19$ & $28-31$ & $4-5$ & $3.5-5$ & Lundholm et al. 2003 \\
\hline P. caciantha & Lanceolate & $58-85$ & $2.5-3.0$ & $15-18$ & $28-31$ & $2-7$ & $4-5$ & Teng et al. 2013 \\
\hline P. abrensis & $\begin{array}{l}\text { Linear to lanceolate } \\
\text { and symmetrical }\end{array}$ & $66.5-74.1$ & $1.7-2.5$ & $16-22$ & $30-37$ & $1-4$ & $4-6$ & Orive et al. 2013 \\
\hline P. fukuyoi & $\begin{array}{l}\text { Linear to lanceolate } \\
\text { and symmetrical }\end{array}$ & $74-81$ & $1.5-1.9$ & $17-19$ & $32-34$ & $2-3(4)$ & $5-6$ & Lim et al. 2013 \\
\hline P. lundholmiae & $\begin{array}{l}\text { Lanceolate, } \\
\text { symmetrical }\end{array}$ & $63-73$ & $1.7-2.3$ & $16-18$ & $28-34$ & $1-2(3)$ & $4-6$ & Lim et al. 2013 \\
\hline P. batesiana & $\begin{array}{l}\text { Lanceolate and } \\
\text { symmetrical }\end{array}$ & $84-86$ & $1.8-2.2$ & $15-19$ & $29-32$ & $2-3$ & $5-6$ & Lim et al. 2013 \\
\hline P. cuspidate & Lanceolate & $30-73$ & $1.4-2.0$ & $19-25$ & $35-44$ & 2 & $4-6$ & Lundholm et al. 2003 \\
\hline P. fryxelliana & Lanceolate & $30-54$ & $2.1-2.5$ & (17) $18-25$ & $34-40$ & (1) $2-3$ & $5-6(7)$ & Lundholm et al. 2012 \\
\hline P. hasleana & $\begin{array}{l}\text { Lanceolate, } \\
\text { symmetrical }\end{array}$ & $37-79$ & $1.5-2.8$ & $13-20$ & $31-40$ & $2-6$ & $5-6$ & Lundholm et al. 2012 \\
\hline P. pseudodelicatissima & $\begin{array}{l}\text { Linear and } \\
\text { symmetrical }\end{array}$ & $54-87$ & $0.9-1.6$ & $20-25$ & $36-43$ & 2 & $5-6$ & Lundholm et al. 2003 \\
\hline P. mannii & Linear & $33-130$ & $1.7-2.6$ & $17-25$ & $30-40$ & $2-7$ & $4-6$ & Amato et al. 2008 \\
\hline P. calliantha & Linear & $41-98$ & $1.3-1.8$ & $15-22$ & $34-39$ & $7-10$ & $4-6$ & Lundholm et al. 2003 \\
\hline P. circumpora & $\begin{array}{c}\text { Lanceolate and } \\
\text { asymmetrical }\end{array}$ & $71-88$ & $2.2-2.7$ & $15-19$ & $32-35$ & $>7$ & $1-4$ & Lim et al. 2012 \\
\hline
\end{tabular}


Some species of Pseudo-nitzschia are cosmopolitan and are often observed in plankton samples of tropical waters. At least 16 species of Pseudo-nitzschia have now been shown to be toxigenic (reviewed in Lelong et al. 2012; Fernandes et al. in press; Teng et al. in press), although some strains of the same species are not always toxic in culture (Lelong et al. 2012; Trainer et al. 2012). Pseudo-nitzschia caciantha is commonly found in the tropics (Lundholm et al. 2003; Teng et al. 2013), but there has been no documentation of this species from Vietnamese waters (Skov et al. 2004; Doan et al. 2013). Cells observed in this study morphologically resemble $P$. caciantha, as described in Lundholm et al. (2003) and Teng et al. (2013), especially the diagnostic features of the poroid structure (Fig. 3, Table 1). The cells have 2-6 hymen sectors (mainly 4-5), which is similar to that described in Teng et al. (2013) and this distinguishes it from $P$. lundholmiae, $P$. batesiana and $P$. abrensis. It differs from $P$. cuspidata, $P$. pseudodelicatissima, P. mannii, P. calliantha, P. circumpora, P. plurisecta, P. fukuyoi, P. hasleana and $P$. fryxelliana by having $28-31$ striae in $10 \mu \mathrm{m}$. The morphological characteristics of the eight toxic isolates in this study were similar to those of $P$. caciantha. The presence or absence of a central interspace in species of the $P$. pseudodelicatissima complex is a taxonomicinformative character (Teng et al. 2013). Unfortunately, our TEM micrograph did not show the central part of the valve, thus we could not confirm the presence orabsence of this character. As detail genetic information of the isolates is not available to support the species identity. Hence, the species in this study was designated as $P$. cf. caciantha. This is the first record of $P$. cf. caciantha in Vietnamese waters.

Previously, $P$. caciantha was reported as non-detectable for DA production (Lundholm et al. 2003). Although DA per cell in $P$. cf. caciantha cultures was not quantitatively determined by HPLC analysis, DA was detected in the extracts $\left(111-244 \mathrm{ng} \cdot \mathrm{mL}^{-1}\right)$. LC-MS/MS analysis also confirmed the presence of DA in culture extracts. This study is therefore the first report of DA production in $P$. cf. caciantha. Further studies are required to determine cellular DA levels at different stages of the growth curve of this species. No other toxigenic Pseudo-nitzschia species or Nitzschia navis-varingica, another DA producer in Vietnamese waters (Kotaki et al. 2000; Lundholm and Moestrup 2000), were observed in net samples in this study. Extracts from $P$. brasiliana and $P$. pungens cultures collected at the same time as $P$. cf. caciantha did not show any detectable DA. Therefore, it was very likely that $P$. cf. caciantha contributed to the DA contamination in S. versicolor in Nha Phu Bay.

Unfortunately, our $P$. cf. caciantha cultures lost their ability to produce toxin after 3-4 generations and they then died after a few weeks. A similar finding was reported for the highly toxic species, $P$. multiseries (Villac et al. 1993). The availability of essential nutrients may be necessary to promote the growth and toxicity of these species (reviewed in Lundholm et al. 2012; Trainer et al. 2012). Bacteria are also reported to influence DA production in Pseudo-nitzschia (reviewed in Lelong et al. 2012). Therefore, studies on associated bacterial flora and their 
relationship with the production of DA should be studied. Our attempts to re-culture $P$. cf. caciantha for further studies of DA production was not successful, because this species has not reappeared in plankton samples collected in Nha Phu Bay in subsequent years.

\section{Conclusion}

This is the first report of Pseudo-nitzschia cf. caciantha in Vietnamese waters. This is the first report of $P$. cf. caciantha as a producer of DA. Furthermore, it was most likely that $P$. cf. caciantha was the source of the DA contamination in the thorny oyster Spondylus versicolor, in Vietnam. DA accumulation and depuration in this bivalve and other shellfish should be investigated further. The toxigenic $P$. cf. caciantha and DA levels in shellfish should be included in monitoring programmes to ensure that seafood products from affected areas meet the safety requirements for human consumption and export.

\section{Acknowledgements}

This study was funded by project 106.99-2010.22 - NAFOSTED, Vietnam. We wish to express our appreciation to Mrs. Leni Yap, University of Tokyo, Japan for her help in TEM work. We sincerely thank the two reviewers for their excellent comments and editing to improve our manuscript as well as for their suggestions on the future directions for our work.

\section{References}

Amato, A. and M. Montresor. 2008. Morphology, phylogeny, and sexual cycle of Pseudo-nitzschia mannii sp. nov. (Bacillariophyceae): a pseudo-cryptic species within the P. pseudodelicatissima complex. Phycologia 47:487-497.

Bates, S.S., C.J. Bird, A.S.W. de Freitas, R. Foxall, M. Gilgan, L.A. Hanic, G.R. Johnson, A.W. McCulloch, P. Odense, R. Pocklington, M.A. Quilliam, P.G. Sim, J.C. Smith, D.V. Subba Rao, E.D.C. Todd, J.A. Walter and J.L.C. Wright. 1989. Pennate diatom Nitzschia pungens as the primary source of domoic acid, a toxin in shellfish from eastern Prince Edward Island, Canada. Canadian Journal of Fisheries and Aquatic Sciences 46:1203-1215.

Bates, S.S., D.L. Garrison, and R.A. Horner. 1998. Bloom dynamics and physiology of domoic-acid-producing Pseudo-nitzschia species. In: Physiological ecology of harmful algal blooms (eds. D.M. Anderson, A.D. Cembella and G.M. Hallegraeff), pp. 267-292. Springer-Verlag, Heidelberg.

Dao, V.H., Y. Takata, S. Sato, Y. Fukuyo and M. Kodama. 2006. Domoic acid in a bivalve Spondylus cruentus in Nha Trang Bay, Khanh Hoa Province, Vietnam. Coastal Marine Science 30:130-132.

Dao, V.H., Y. Takata, T. Omura, S. Sato, Y. Fukuyo and M. Kodama. 2009a. Seasonal variation of domoic acid in Spondylus versicolor in association with that in plankton samples in Nha Phu Bay, Khanh Hoa, Vietnam. Fisheries Science 75:507-512. 
Dao, V.H., Y. Takata, T. Omura, N.T. Dung, N.T. Hong, S. Sato, Y. Fukuyo and M. Kodama. 2009b. Domoic acid in small-sized plankton in Nha Phu Bay, Khanh Hoa Province, Vietnam. La mer 46:117-120.

Doan, N.H., N.T. Tin, N.T.M. Anh and N.N. Lam. 2013. Species composition and cell density variation of diatoms Pseudo-nitzschia spp. in coastal waters of Khanh Hoa, Vietnam. Proceedings of the International Conference on "Bien Dong 2012" (Eds. Bui, H.L., V.S.Tuan and N.N. Lam). 12-14 September, 2012 (in Vietnamese with English abstract), pp.159-268.

Fernandes, L.F., K.A. Hubbard, M. Richlen, J. Smith, S.S. Bates, J. Ehrman, C. Léger, L.L. Mafra Jr., D. Kulis, M. Quilliam, D. Erdner, K. Libera, L. McCauley, and D. Anderson. in press. Diversity and toxicity of the diatom Pseudo-nitzschia Peragallo in the Gulf of Maine, Northwestern Atlantic Ocean.Deep-Sea Res.II. http://dx.doi.org/10.1016/j.dsr2.2013.06.022.

Hargraves, P.E. and R.R.L. Guillard. 1974. Structural and physiological observations on some small marine diatoms. Phycologia 13:163-172.

Howard, M.D.A., W.P. Cochlan, N. Ladizinsky and R.M. Kudela. 2007. Nitrogenous preference of toxigenic Pseudo-nitzschia australis (Bacillariophyceae) from field and laboratory experiments. Harmful Algae 6:206217.

Kodama, M. and Y. Kotaki. 2005. Domoic acid. In: The manual for the method of food sanitation test (ed. Ministry of Health, Labour and Welfare), pp. 666-673. Japan Food Hygienic Association, Tokyo (in Japanese).

Kotaki, Y., K. Koike, M. Yoshida, C.V. Thuoc, N.T.M. Huyen, N.C. Hoi, Y. Fukuyo and M. Kodama. 2000. Domoic acid production in Nitzschia sp. (Bacillariophyceae) isolated from a shrimp-culture pond in Do Son, Vietnam. Journal of Phycology 36:1057-1060.

Lelong, A.L., H.H. Hégaret, P. Soudant and S.S. Bates. 2012. Pseudo-nitzschia (Bacillariophyceae) species, domoic acid and amnesic shellfish poisoning: revisiting previous paradigms. Phycologia 51:168-216.

Lim, H.C., S.N.P. Su, H. Mohamed-Ali, Y. Kotaki, C.P. Leaw and P.T. Lim. 2010. Toxicity of diatom Pseudonitzschia (Bacillariophyceae) analyzed using high performance liquid chromatography (HPLC). Journal of Science and Technology of the Tropics 6:S116-S119.

Lim, H.C., C.P. Leaw, S.N.P. Su, N. Mohammad Noor, N. Lundholm, G. Usup, Y. Kotaki and P.T. Lim. 2012. Morphology and molecular characterization of Pseudo-nitzschia (Bacillariophyceae) from Malaysian Borneo, including a new species of Pseudo-nitzschia circumpora sp. nov. Journal of Phycology 48:1232-1247.

Lim, H.C., S.T. Teng, C.P. Leaw and P.T. Lim. 2013. Three novel species in the Pseudo-nitzschia pseudodelicatissima complex: P. batesiana sp. nov., P. lundholmiae sp. nov. and $P$. fukuyoi sp. nov. (Bacillariophyceae), from the Strait of Malacca, Malaysia. Journal of Phycology 49:902-916.

Lundholm, N. and Ø. Moestrup. 2000. Morphology of the marine diatom Nitzschia navis-varingica, sp. nov. (Bacillariophyceae), another producer of the neurotoxin domoic acid. Journal of Phycology 36:1162-1174. 
Lundholm, N., Ø. Moestrup, G.R. Hasle and K. Hoef-Emden. 2003. A study of the Pseudo-nitzschia pseudodelicatissima/cuspidata complex (Bacillariophyceae): What is P. pseudodelicatissima? Journal of Phycology 39:797-813.

Lundholm, N., S.S. Bates, K.A. Baugh, B.D. Bill, L.B. Connell, C. Léger and V.L. Trainer. 2012. Cryptic and pseudo-cryptic diversity in diatoms - with descriptions of Pseudo-nitzschia hasleana sp. nov. and $P$. fryxelliana sp. nov. Journal of Phycology 48:436-454.

Novaczek, I., M.S. Madhyastha, R.F. Ablett, A. Donald, G. Johnson, M.S. Nijjar and D.E. Sims. 1992. Depuration of domoic acid from blue mussels (Mytilus edulis). Canadian Journal of Fisheries and Aquatic Sciences 49:312318 .

Ogata, T., T. Ishimaru and M. Kodama. 1987. Effects of water temperature and light intensity on growth rate and toxicity change in Protogonyaulax tamarensis. Marine Biology 95:217-220.

Orive, E., L. Pérez-Aicua, H. David, K. García-Etxebarria, A. Laza-Martínez, S. Seoane and I. Miguel. 2013. The genus Pseudo-nitzschia (Bacillariophyceae) in a temperate estuary with description of two new species: Pseudo-nitzschia plurisecta sp. nov. and Pseudo-nitzschia abrensis sp. nov. Journal of Phycology 49:11921206.

Perl, T.M., L. Bédard, T. Kosatsky, J.C. Hockin, E.C.D. Todd and R.S. Remis. 1990. An outbreak of toxic encephalopathy caused by eating mussels contaminated with domoic acid. New England Journal of Medicine 322:1775-1780.

Quilliam, M.A. 2003. Chemical methods for domoic acid, the amnesic shellfish poisoning (ASP) toxin. In: Manual on harmful marine microalgae, Monographs on Oceanographic Methodology (eds. G.M. Hallegraeff, D.M. Anderson and A.D. Cembella), pp. 247-266. Intergovernmental Oceanographic Commission of UNESCO, Paris.

Quilliam, M.A., P.G. Sim, A.W. McCulloch and A.G. McInnes. 1989. High-performance liquid chromatography of domoic acid, a marine neurotoxin, with application to shellfish and plankton. International Journal of Environmental and Analytical Chemistry 36:139-154.

Skov, J., N. Lundholm, Ø. Moestrup and J. Larsen. 1999. Potentially toxic phytoplankton. 4. The diatom genus Pseudo-nitzschia (Diatomophyceae/Bacillariophyceae). In: ICES identification leaflets for phytoplankton, Leaflet No. 185 (ed. J.A. Lindley), pp. 1-23. International Council for the Exploration of the Sea, Copenhagen.

Skov, J., T.P. Ton and T.B.L. Do. 2004. Bacillariophyceae. In: Potentially toxic microalgae of Vietnamese waters. In: Opera Botanica Vol 140 (eds. J. Larsen and N.L. Nguyen), pp. 23-51. Council for Nordic Publications in Botany, Copenhagen.

Takahashi, E., Q. Yu, G. Eaglesham, D.W. Connell, J. McBroom, S. Costanzo and G.R. Shaw. 2007. Occurrence and seasonal variations of algal toxins in water, phytoplankton and shellfish from North Stradbroke Island, Queensland, Australia. Marine and Environmental Research 64:429-442.

Takata, Y., S. Sato, V.H. Dao, U.M. Montojo, L. Thaithaworn, S. Kamolsiripichaiporn, K. Kotaki, Y. Fukuyo and M. Kodama. 2009. Occurrence of domoic acid and isomers in tropical bivalves. Fisheries Science 75:473-480. 
Teng, S.T., C.P. Leaw, H.C. Lim and P.T. Lim. 2013. The genus Pseudo-nitzschia (Bacillariophyceae) in Malaysia, including new records and a key to species inferred from morphology-based phylogeny. Botanica Marina 56:375-398.

Teng, S.T., H.C. Lim, P.T. Lim, V.H. Dao, S.S. Bates, and C.P. Leaw. in press. Pseudo-nitzschia kodamae sp. nov. (Bacillariophyceae), a toxigenic species from the Strait of Malacca, Malaysia. Harmful Algae. DOI: 10.1016/j.hal.2014.02.005.

Todd, E.C.D. 1990. Amnesic shellfish poisoning - A new seafood toxin syndrome. In: Toxic marine phytoplankton (eds. E. Granéli, B. Sundström, L. Edler and D.M. Anderson), pp. 504-508. Elsevier Science Publishing.

Trainer, V.L., W.P. Cochlan, A. Erickson, B.D. Bill, F.H. Cox, J.A. Borchert and K.A. Lefebvre. 2007. Recent domoic acid closures of shellfish harvest areas in Washington State inland waterways. Harmful Algae 6:449459.

Trainer, V.L., S.S. Bates, N. Lundholm, A.E. Thessen, W.P. Cochlan, N.G. Adams and C.G. Trick. 2012. Pseudonitzschia physiological ecology, phylogeny, toxicity, monitoring and impacts on ecosystem health. Harmful Algae 14:271-300.

Villac, M.C., D.L. Roelke, F.P. Chavez, L.A. Cifuentes and G.A. Fryxell. 1993. Pseudo-nitzschia australis Frenguelli and related species from the west coast of the U.S.A.: occurrence and domoic acid production. Journal of Shellfish Research 12:457-465.

Received: 01/11/2013; Accepted: 28/02/2014(MS13-79) 